\title{
Turkey Meat. Seasonal Effect on Meat Quality and on Dead on Arrival Index in a Commercial Plant
}

\author{
Rafael Humberto de Carvalho ${ }^{1 *}$, Adriana Lourenço Soares ${ }^{2}$, Paulo Donizete Guarnieri ${ }^{2}$, \\ Alexandre Oba ${ }^{1}$, Elza Iouko Ida ${ }^{2}$, Massami Shimokomaki ${ }^{1}$ \\ ${ }^{1}$ Universidade Estadual de Londrina - Animal Science. Londrina, Paraná, Brazil; ${ }^{2}$ Universidade Estadual de \\ Londrina - Food Science and Technology. Londrina, Paraná, Brazil
}

\begin{abstract}
The objective of this study was to determine the incidence of Pale, Soft, Exudative (PSE) meat and to characterize the Dark, Fim, Dry (DFD) meat as well as the Dead on Arrival (DOA) index in a commercial turkey slaughterhouse in southern Brazil during the summer and winter seasons. The journeys $(n=64)$ were over a distance of $36 \pm 20 \mathrm{~km}$ and took approximately $95 \pm 20 \mathrm{~min}$. Color $\left(L^{*}\right)$ and $\mathrm{pH}$ distribution of turkey breast meat $(n=5,352)$ were evaluated from different farms $(n=64)$ during the 2015-2016 years. The $p H$, water-holding capacity, color $\left(L^{*}, a^{*}\right.$, $\left.b^{*}\right)$ were used to establish cutoff values for DFD meat $\left(L^{*}<44.0\right.$ and $\left.p H>5.90\right)$ and presented correlation among them. The $L^{*}$ value was the highest during the summer $(P<0.01)$, indicating the highest incidence of PSE meat $(28.35 \%)$, and lowest during winter, observing the highest incidence of DFD meat (10.3\%). Finally, the obtained summer DOA index was $0.23 \%$ higher in relation to winter.
\end{abstract}

Keywords: Animal Welfare, Color Meat, DFD meat, PSE meat, Slaughterhouse.

\footnotetext{
*Author for correspondence: rafael.carvalho@uel.br
} 


\section{INTRODUCTION}

The production and consumption of turkey meat have increased rapidly around the world. This production raised around 6\% from 5,610 million pounds (2015) to 5,981 million pounds (2016) and Brazil produced over 330 mil pounds (2015) according to USDA ${ }^{1}$. The Brazilian poultry industry has various critical factors to keep the meat qualities throughout the year because Brazil having a continental size is located within tropical and subtropical zones and the birds are frequently exposed to different weather conditions ${ }^{2}$. Problems with the quality of meat are generally caused by biochemical and morphological changes of muscles (antemortem) and by processing (postmortem $)^{3-4}$. Two conditions are known under stress pre-slaughter: pale, soft and exudative (PSE), and dark, firm and dry (DFD) that are developed as the result of stress in the short and long-term, respectively ${ }^{5}$.

In summer, the climatic effect can induce PSE problem in birds ${ }^{6}$, as well as processing after slaughtering ${ }^{7}$. Owens et al. ${ }^{8}$ and Barbut et al. ${ }^{9}$ suggested that PSE poultry breasts can be classified by color in the processing plant due to its high correlation with the functional properties ${ }^{2,10}$.

Long stress conditions before slaughter influences the level of glycogen and final $\mathrm{pH}$ of breast muscle ${ }^{5}$ resulting in a high water holding capacity (WHC) and reduced shear force (SF) ${ }^{11}$, characteristics which are typical of DFD meat. Another interesting aspect is that the birds are sensitive to seasons by being homoeothermic animals ${ }^{12-13}$. The objective of this work was to evaluate the incidence of PSE meat and characterize the DFD meat in turkey breast meat in a Brazilian commercial processing plant during summer and winter seasons.

\section{MATERIAL AND METHODS}

\section{Animals}

This study was conducted during the summer and winter seasons from December 2015 to September 2016 in a commercial plant in the Chapecó city region (Latitude: $27^{\circ} 05^{\prime} 47^{\prime \prime} \mathrm{S}$; Longitude: 52 $37^{\circ}$ 06" W; Altitude: $674 \mathrm{~m})$ Santa Catarina State, Brazil. The transportation activity conditions from the farm to the turkey commercial processing plant were described in details in ${ }^{2}$. The weather conditions in this region were characterized by the minimum and maximum temperatures, and the relative humidity as measured using a Kestrel 4000 instrument (Nielsen-Kellerman, Boothwyn, PA, USA) as seen in Table 1 . The feed was removed 9 to $12 \mathrm{~h}$ before slaughter, and water was provided ad libitum. The animals were manually placed into crates at a density of 8 birds each and installed within the truck open container. The average catching and loading time was 24 min. Turkeys were handled in accordance with the principles and procedures outlined by the Londrina State University Animal Care and Use Ethical Committee (Process \#167/2015).

Table 1. Samples, period, animals and climatic characteristics of the region.

\begin{tabular}{lcc}
\hline & Summer $(2015 / 2016)$ & Winter (2016) \\
\hline Lineage and gender & Nicholas-700, male & Nicholas-700, male \\
Weight & $18 \pm 2 \mathrm{~kg}$ & $18 \pm 2 \mathrm{~kg}$ \\
Number of fillets analyzed & 2674 & 2678 \\
Days of sampling & 56 & 73 \\
Temperature range & 24 to $36^{\circ} \mathrm{C}$ & -2 to $24^{\circ} \mathrm{C}$ \\
Relative humidity range & 43 to $67 \%$ & 42 to $65 \%$ \\
\hline
\end{tabular}


The animals were reared on 64 turkey farms under a cooperative system and subsequently transported over a distance of $36 \pm 20 \mathrm{~km}$ for a journey that took approximately $95 \pm 20 \mathrm{~min}$. Upon arrival at the slaughterhouse facilities, the birds were placed in a holding area under water mist and ventilation for $70 \mathrm{~min}$ before slaughtering. The animals were sacrificed according to standard industry practices, which consisted of hanging, electrically stunning, bleeding, scalding, defeathering, evisceration, cooling the carcass through a tunnel of cold air $\left(-6{ }^{\circ} \mathrm{C}\right.$ for $\left.6 \mathrm{~h}\right)$ and deboning ${ }^{14}$. Subsequently, the breast meat samples (Pectoralis major) were collected and refrigerated at $4{ }^{\circ} \mathrm{C}$ until completing $24 \mathrm{~h}$ to measure the color $\left(\mathrm{L}^{*}, \mathrm{a}^{*}\right.$ and $\mathrm{b}^{*}$ values), $\mathrm{pH}$ and water holding capacity (WHC) and thus evaluating the occurrence of PSE ${ }^{2}$ and DFD meat.

\section{Transport of Truck Container Microenvironment Assessment}

Six portable weather meter devices with bidirectional Kestrel anemometers and data logging capability were set to take measurements at an interval of 30 seconds during the journeys ${ }^{15}$. The transport temperature (TT), transport relative humidity (TRH), air ventilation (AV), ambient temperature (AT), ambient relative humidity (ARH), heat index (HI) and wind chill (WC) values were simultaneously measured as in Spurio et al. ${ }^{6}$, allowing for a representative analysis of the heterogeneous distribution of the thermal microenvironment within the loaded vehicle. The weather conditions in moment of transport were characterized by temperatures (AT), and the relative humidity (ARH). HI or apparent temperature is an index that combines temperature and $\mathrm{RH}$ to measure the observed equivalent temperature ${ }^{15}$. HI is usually higher than the temperature evaluated by the dry bulb temperature ${ }^{16}$. WC or apparent temperature is an index that combines air temperature and air ventilation to measure the perceived equivalent temperature ${ }^{17}$.

\section{Color and pH Measurements in Fresh Breast Meat}

This evaluation was performed using a Minolta CR-400 colorimeter, taking five different reading points per sample for color determination $\left(\mathrm{L}^{*}, \mathrm{a}^{*}\right.$ and $\mathrm{b}^{*}$ ), as described by Carvalho et al. ${ }^{2}$. The $\mathrm{pH}$ was measured (in duplicate) by inserting electrodes into the pectoralis major $\mathrm{m}$. as described in Carvalho et al. ${ }^{14}$. The meat samples $(n=5,352$; summer $=2,674$; winter $=2,678)$ were classified as PSE according to their $\mathrm{L}^{*}$ values, with $\mathrm{L}^{*}>53$ and $\mathrm{pH}<$ 5.60 , considered typical of PSE turkey meat, as thoroughly discussed in Carvalho et al. ${ }^{2}$.

\section{Water Holding Capacity (WHC)}

This measurement was carried out based on the technique of Hamm ${ }^{18}$, as described in Carvalho et al. ${ }^{19}$. After $24 \mathrm{~h}$ postmortem, samples were collected from the cranial side of the breast fillets and cut into cubes $2.0 \pm$ $0.10 \mathrm{~g}$. They were first carefully placed between 2 pieces of filter paper on acrylic plates and then left under a $10-\mathrm{kg}$ weight for $5 \mathrm{~min}$. The samples were weighed and WHC was determined using the weight of exudate water and the following equation: $100-[(\mathrm{Wi}-\mathrm{Wf} / \mathrm{Wi}) \mathrm{X} 100]$, where Wi and Wf are the initial and final sample weights, respectively. A total of 104 samples was analyzed in triplicate. 


\section{Mortality Evaluated by Dead on Arrival (DOA)}

A total 30,720 turkeys were transported from 64 different farms. The percentage of DOA per loaded truck was calculated by counting each dead bird during the hanging step at the slaughtering plant, taking care to observe the truck region from which the birds were collected ${ }^{6}$.

DOA $=$ Number of birds dead / Number of birds transported

\section{Statistical Analysis}

The Statistica software for Windows 13.0 (StatSoft, Tulsa, USA) was used. Student's t-test at $1 \%$ probability $(\mathrm{P}<0.01)$ was used for comparing the differences between the two treatments of summer and winter, and Pearson's correlation $(\mathrm{P}<0.01$ and $\mathrm{P}<0.05)$ coefficient to assess the correlation among $\mathrm{pH}, \mathrm{a}^{*}, \mathrm{~b}^{*}, \mathrm{~L}^{*}$ values and $\mathrm{WHC}$.

\section{RESULTS AND DISCUSSION}

\section{Summer and Winter Weather Conditions in the Farm Region}

Table 2 shows the AT, TT, ARH, TRH, AV, HI and WC during summer and winter seasons. The AT in the summer season showed approximately 5.5 times higher $(\mathrm{P}<0.01)$ compared to the winter. TT values in the summer season showed 3.1 times higher $(\mathrm{P}<0.01)$ compared to winter. The relative humidity (TRH and ARH) was not significantly different $(\mathrm{P} \geq 0.01)$ as well as the air ventilation (AV) values. HI in the summer season showed a high value of $30.04{ }^{\circ} \mathrm{C}$ and obviously, the WC in winter showed a lower value $\left(10.6{ }^{\circ} \mathrm{C}\right)$. WC in summer was not measured because the temperatures need to be between $-50^{\circ} \mathrm{C}$ and $10{ }^{\circ} \mathrm{C}{ }^{17}$.

Table 2. Mean values of ambient temperature (AT), transport temperature (TT), ambient relative humidity (ARH), transport relative humidity (TRH), air ventilation (AV), heat index (HI) and wind chill (WC) performed under two treatments: summer and winter during turkey transportation.

\begin{tabular}{lccc}
\hline & Summer & Winter & P-value \\
\hline AT $\left({ }^{\circ} \mathrm{C}\right)$ & $33.02^{\mathrm{a}} \pm 0.51$ & $5.97^{\mathrm{b}} \pm 0.87$ & $<0.001$ \\
${ }^{\#} \mathrm{TT}\left({ }^{\circ} \mathrm{C}\right)$ & $33.87^{\mathrm{a}} \pm 2.84$ & $10.89^{\mathrm{b}} \pm 4.47$ & $<0.001$ \\
$\mathrm{ARH}(\%)$ & $48.99^{\mathrm{a}} \pm 4.57$ & $44.92^{\mathrm{a}} \pm 5.67$ & 0.948 \\
${ }^{\#} \mathrm{TRH}(\%)$ & $59.84^{\mathrm{a}} \pm 11.90$ & $59.42^{\mathrm{a}} \pm 12.93$ & 0.976 \\
${ }^{\#} \mathrm{AV}(\mathrm{m} / \mathrm{s})$ & $1.31^{\mathrm{a}} \pm 1.16$ & $1.10^{\mathrm{a}} \pm 1.12$ & 0.626 \\
${ }^{\#} \mathrm{HI}\left({ }^{\circ} \mathrm{C}\right)$ & $41.0 \pm 4.32$ & - & \\
${ }^{\#} \mathrm{WC}\left({ }^{\circ} \mathrm{C}\right)$ & - & $10.6 \pm 3.65$ & \\
\hline
\end{tabular}

${ }^{\mathrm{a}-\mathrm{b}}$ Means \pm standard deviation in the same line with no common superscripts are significantly different by Student $\mathrm{t}-$ test $(\mathrm{P}<0.01)$. \#Parameters analyzed during the transport of turkeys.

\section{Meat Characteristics in the Summer Season}

Color variation of fresh turkey breast meat in summer is shown in Figure $1 \mathrm{~A}$. The $\mathrm{L}^{*}$ values varied from 40.28 (dark) to 63.73 (pale), and the average value was 50.88 , the variance $(8.51)$, skewness $(-0.12)$, and kurtosis $(-0.10)$ were calculated $(\mathrm{P} \geq 0.05)$. The $\mathrm{pH}$ variation is shown in Figure $1 \mathrm{~B}$, and their values varied from 5.49 to 6.03 , and the average value was 5.72 , the variance (0.007), skewness (-0.08), and kurtosis (-0.19) were calculated $(\mathrm{P} \geq 0.05)$. 
There was significant $(\mathrm{P}<0.01)$ negative Pearson correlation (Figure 2) between the $\mathrm{pH}$ and $\mathrm{L}^{*}$ values, with a value of the coefficient of -0.55 . During the summer season, poultry breast meat showed high $\mathrm{L}^{*}$ and low $\mathrm{pH}$ values. In Brazilian summer high $\mathrm{L}^{*}$ values were found in poultry ${ }^{6,20-22}$, and this phenomenon obviously is related to the season climate (Table 1) being the heat located outside the comfort zone $\left(18 \text { to } 30^{\circ} \mathrm{C}\right)^{6,22-23}$. During the preslaughter phases, the microclimate of transport truck container is also an important factor that influences the meat quality (Table 2). During the summer season as observed previously unfavorable transport microclimate related in particular to temperature, relative humidity and ventilation resulted in breast meat with high $\mathrm{L}^{*}$ and low $\mathrm{pH}$ values ${ }^{6,21}$.
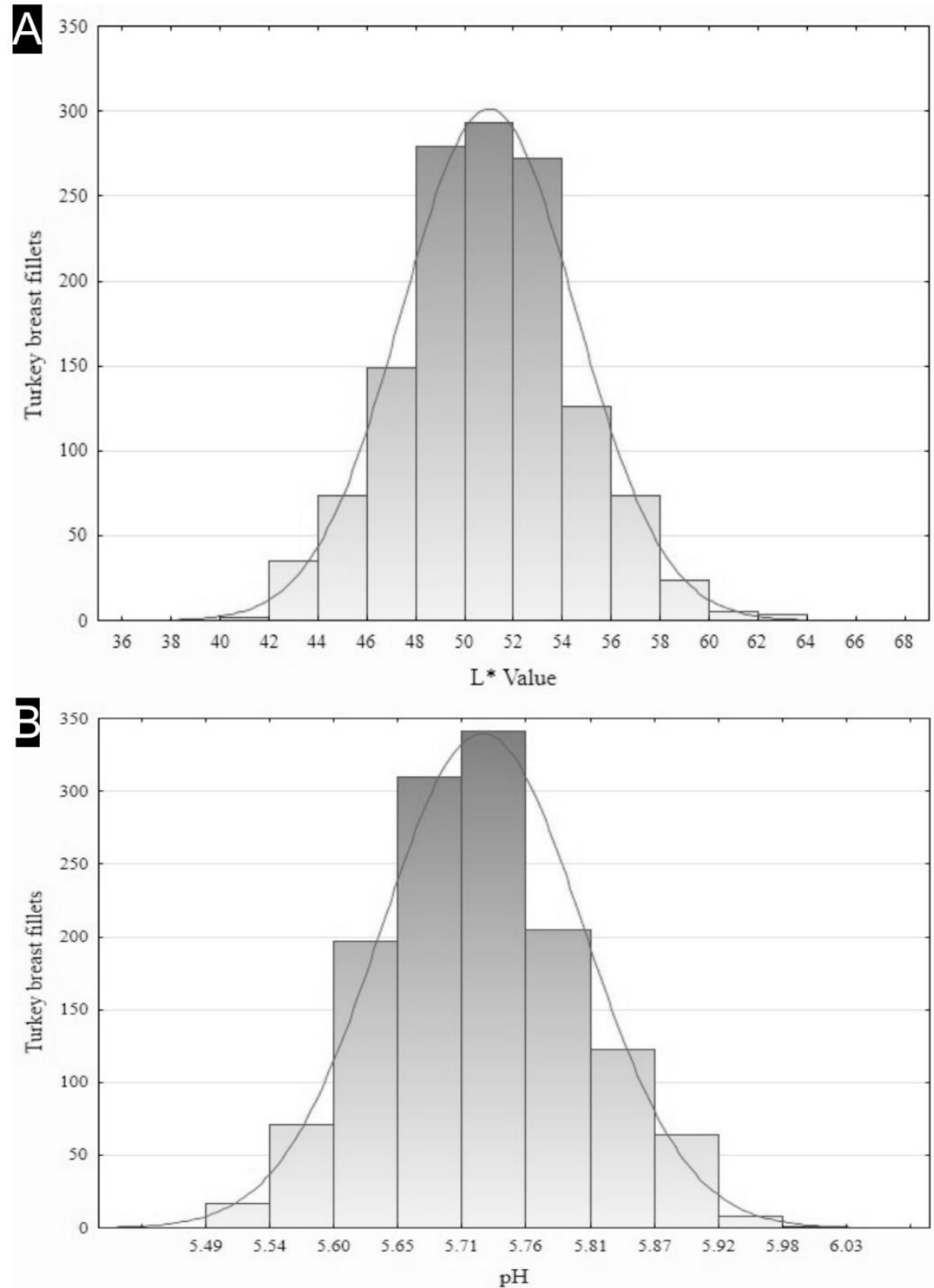

Figure 1. Histograms of turkey breast fillets harvested during summer season. A) showing the distribution of $\mathrm{L}^{*}$ values. B) showing the distribution of $\mathrm{pH}$ values $(n=2,674)$. 


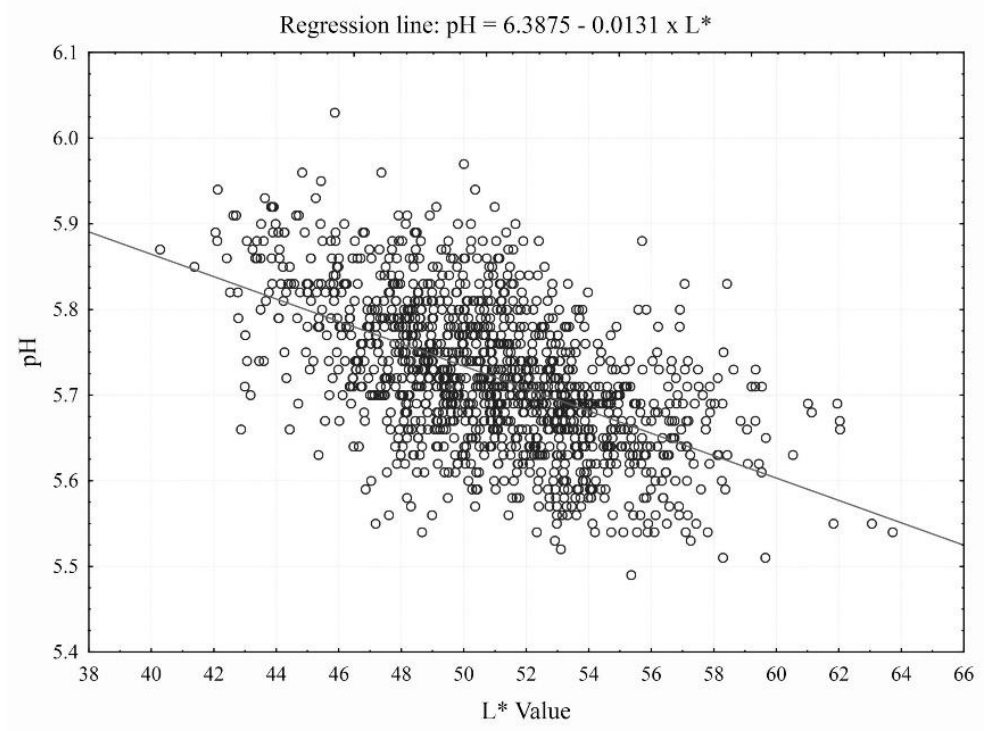

Figure 2. The relationship between $\mathrm{L}^{*}$ and $\mathrm{pH}$ values in turkey breast fillets harvested in summer season $(n=2,674)$. Correlation coefficient of $-0.55(\mathrm{P}<0.01)$.

\section{Meat Characteristics in the Winter Season and DFD Characterization}

Color variation of fresh turkey breast meat during winter season is shown in Figure 3A. The $\mathrm{L}^{*}$ values varied from 36.38 (dark) to 60.69 (pale), and the average value was 47.69 units, the variance (8.81), skewness (-0.11), and kurtosis $(-0.25)$ were calculated $(\mathrm{P} \geq 0.05)$. The $\mathrm{pH}$ variation is shown in Figure $3 \mathrm{~B}$ from 5.59 to 6.20 , and the average value was 5.84 units, the variance (0.009), skewness (-0.16), and kurtosis (-0.26) were calculated $(\mathrm{P} \geq 0.05)$. There was significant $(\mathrm{P}<0.01)$ negative Pearson correlation (Figure 4) between the $\mathrm{pH}$ and $\mathrm{L}^{*}$ values, with a value of the coefficient of 0.61 . Table 3 shows a significant negative Pearson correlation is observed between $\mathrm{L}^{*}$ and $\mathrm{pH}(-0.62, \mathrm{P}<0.01)$ and between $\mathrm{L}^{*}$ and WHC $(-0.47$, $\mathrm{P}<0.01)$. $\mathrm{pH}$ values showed correlations between WHC $(0.31, \mathrm{P}<0.05)$, a* $(-$ $0.43, \mathrm{P}<0.01), \mathrm{b}^{*}(-0.31, \mathrm{P}<0.05)$. 

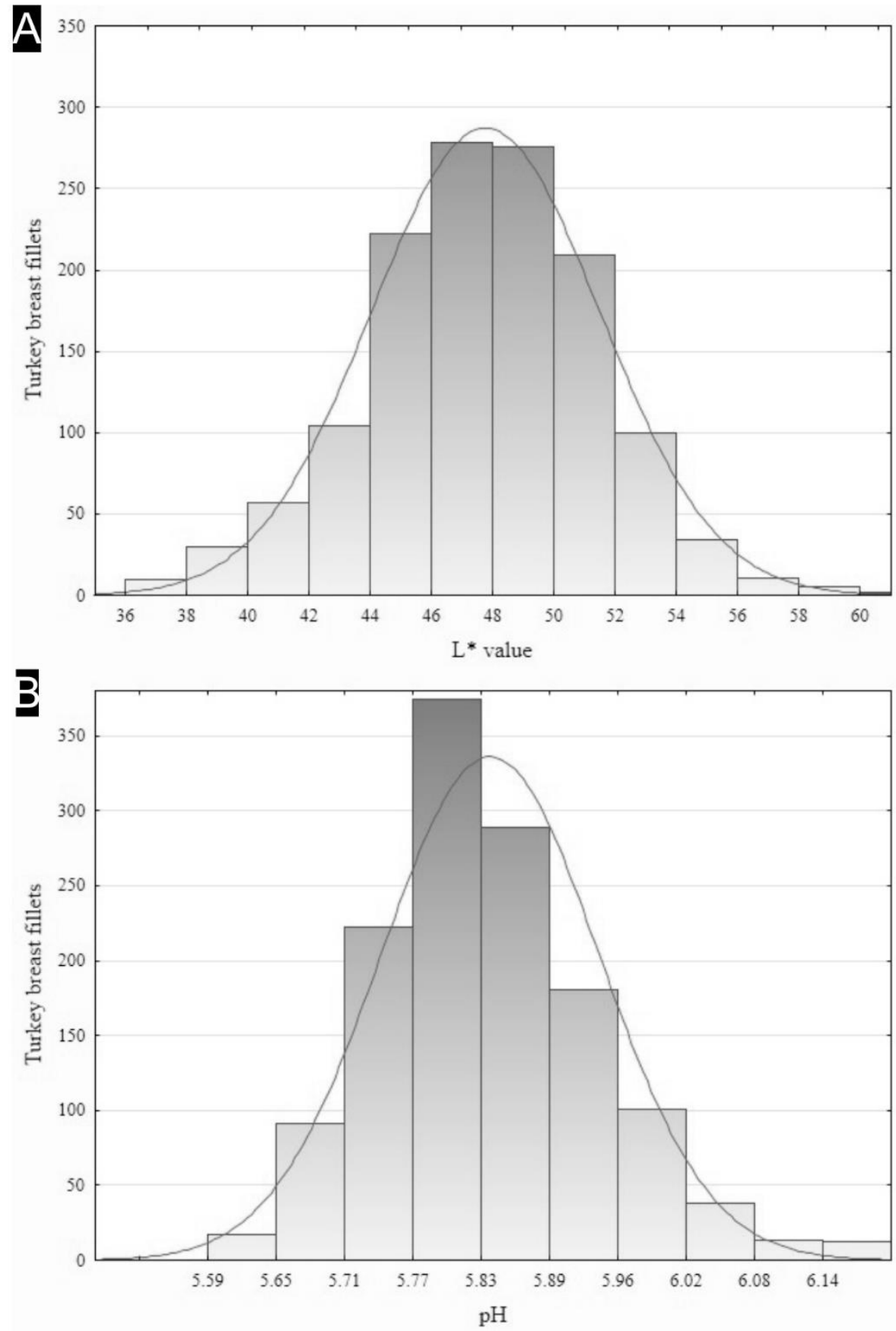

Figure 3. A) Histograms of turkey breast fillets harvested during winter season. A) showing the distribution of $\mathrm{L}^{*}$ values. B) showing the distribution of $\mathrm{pH}$ values $(n=2,678)$.

Table 3. Pearson correlation coefficients among physical measurements of turkey breast meat samples.

\begin{tabular}{cccccccc}
\hline Parameter & $\mathrm{L}^{*}$ & a* & $\mathrm{b}^{*}$ & $\mathrm{pH}$ & WHC \% & Means & $\begin{array}{c}\text { Standard } \\
\text { deviation }\end{array}$ \\
\hline $\mathrm{L}^{*}$ & 1 & - & - & - & - & 48.90 & 2.72 \\
$\mathrm{a}^{*}$ & $0.37^{* *}$ & 1 & - & - & - & 3.86 & 0.95 \\
$\mathrm{~b}^{*}$ & $0.58^{* *}$ & $0.60^{* *}$ & 1 & - & - & 3.56 & 1.27 \\
$\mathrm{pH}$ & $-0.62^{* *}$ & $-0.53^{* *}$ & $-0.71 * *$ & 1 & - & 5.97 & 0.10 \\
$\mathrm{WHC} \%$ & $-0.47^{* *}$ & $-0.43^{* *}$ & $-0.31^{*}$ & $0.31^{*}$ & 1 & 77.16 & 1.88 \\
\hline
\end{tabular}

*Values significantly at $\mathrm{P}<0.05$ unless otherwise stated. $\mathrm{n}=104$. $* *$ Values significantly at $\mathrm{P}<0.01$ unless otherwise stated. $\mathrm{n}=104$. 


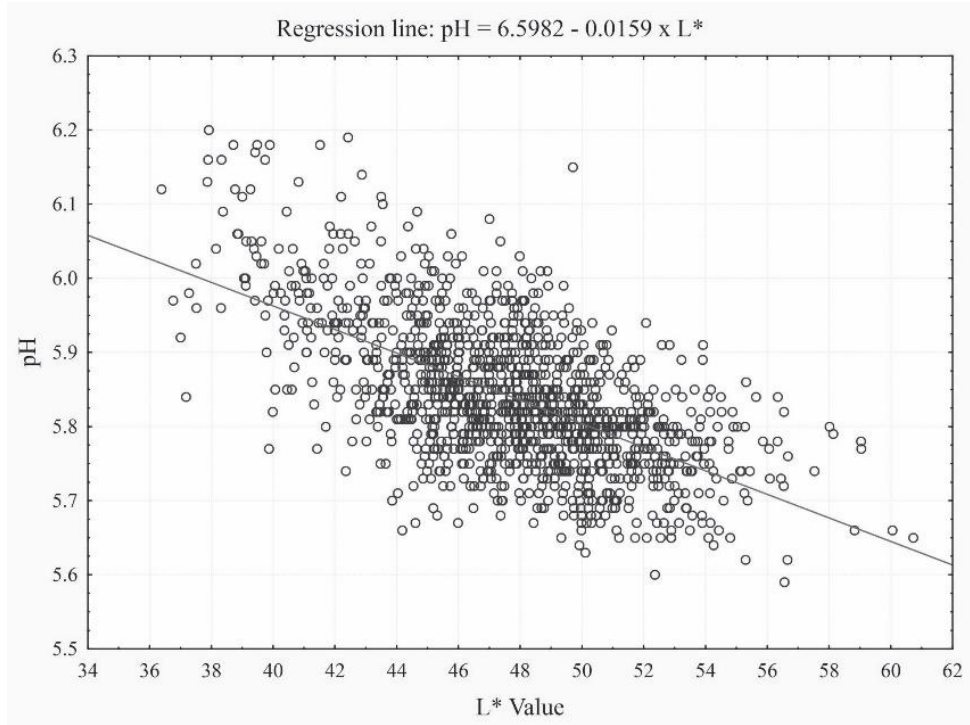

Figure 4. The relationship between $\mathrm{L}^{*}$ and $\mathrm{pH}$ values in turkey breast fillets in winter season $(n$ $=2,678)$. Correlation coefficient of $-0.61(\mathrm{P}<0.01)$.

The methodology for detection or prediction of color abnormalities has recently been a matter of debate because of a single measurement of color is not sufficient for accurate characterization of either PSE and DFD-meat ${ }^{25}$. On the other hand, several authors reported evidence that a color measuring system is an important meat quality tool and is often used as an indicator of PSE meat ${ }^{2,26-29}$.

Owens et al. ${ }^{8}$ reported the incidence of PSE meat in turkeys using parameters such as $\mathrm{L}^{*}, \mathrm{a}^{*}, \mathrm{~b}^{*}, \mathrm{pH}$ and $\mathrm{WHC}$ and found $\mathrm{L}^{*}$ values ranged from 41 to 63 . In addition, the values of $\mathrm{L}^{*}$ were the best predictor of PSE meat condition. According to Barbut ${ }^{29}$, the $\mathrm{L}^{*}$ values were the best predictor of PSE meat condition. According to Barbut ${ }^{29}$, the $\mathrm{L}^{*}$ value of $50 / 51$ correctly identifies turkey meat PSE because this classification presented a significant correlation with WHC. Several works indicated that the $\mathrm{L}^{*}$ parameter can be used for identification of poultry meat abnormalities since that correlated with other attributes such as $\mathrm{pH}$, WHC and drip loss ${ }^{2,8,19,26}$. McCurdy et al. ${ }^{12}$ obtained correlations between $\mathrm{pH}$ and $\mathrm{L}^{*}(-0.62)$, and they suggested an $\mathrm{L}^{*}$ cut off $>50 / 51$ for detection PSE meat.

The color $\left(\mathrm{L}^{*}\right)$ and $\mathrm{pH}$ data from commercial plant were used to show the typical bell-shape distribution obtained (Figure 1 and 3). To characterize the distribution of the $\mathrm{L}^{*}$ and $\mathrm{pH}$ values for each season, the variance, skewness, and kurtosis were calculated. The skewness (indicating a tendency to form a tail towards a certain side of the curve ${ }^{30}$ ) was negative for the summer and winter data, showing a tendency that the skew of the distribution is to the left to form a tail towards the low $\mathrm{L}^{*}$ and $\mathrm{pH}$ values ${ }^{30}$. The kurtosis values also were negative between the seasons. In addition, all parameters were significantly correlated $(\mathrm{P}<0.01 ; \mathrm{P}<0.05)$. As expected, the PSE turkey fillets had higher $\mathrm{L}^{*}$ values, lower muscle $\mathrm{pH}$, and lower WHC compared with the normal and DFD fillets. The DFD turkey fillets had lower $\mathrm{L}^{*}$ values, higher muscle $\mathrm{pH}$, and higher WHC compared with the normal and PSE fillets.

Therefore, using Figures 3A, 3B, 4 and Table 3 we proposed a convenient cutoff value for detection of DFD meat in turkey breast fillets under the conditions of our experiment: DFD meat $=\mathrm{L}^{*}<44$ and $\mathrm{pH}>5.90$. Thus, the results of this experiment associated with our previous one by Carvalho et al. 2 encouraged us to assume the following meat color abnormalities classification: 
i. $\mathrm{L}^{*}>53.00$ and $\mathrm{pH}<5.60=$ PSE meat ${ }^{2}$.

ii. Normal: $53.00 \leq \mathrm{L}^{*} \geq 44.00$; and $5.60 \leq \mathrm{pH} \leq 5.90$.

iii. $\mathrm{L}^{*}<44.00$ and $\mathrm{pH}>5.90=$ DFD meat.

\section{Comparison of Summer versus. Winter Seasons}

In Table 4 is shown the $\mathrm{pH}, \mathrm{L}^{*}, \mathrm{a}^{*}, \mathrm{~b}^{*}$ values and the incidence of PSE and DFD meat and DOA index. The breast meat in the summer showed average $\mathrm{pH}$ value 0.13 lower units, $\mathrm{L}^{*}$ value 3.19 units higher, $\mathrm{a}^{*}$ value lower 0.63 units and $b^{*}$ value lower 0.21 units compared to winter season samples $(\mathrm{P}<0.01)$. In relation to the classification of turkey breast meat in summer, there was $28.35 \%$ incidence of PSE meat and $1.2 \%$ of DFD meat. Conversely, during the winter season the incidence of PSE and DFD meat were $6.7 \%$ and $10.3 \%$, respectively. The DOA index in summer was relatively higher by $0.23 \%$ while in the winter season it was extremely low.

Table 4. Mean values of $\mathrm{pH}, \mathrm{L}^{*}, \mathrm{a}^{*}, \mathrm{~b}^{*}, \mathrm{PSE}$ and DFD meat in turkey breast meat performed under two treatments: summer and winter.

\begin{tabular}{lccc}
\hline & Summer & Winter & P-Value \\
\hline $\mathrm{pH}$ & $5.71^{\mathrm{b}} \pm 0.05$ & $5.84^{\mathrm{a}} \pm 0.06$ & $<0.001$ \\
$\mathrm{~L}^{*}$ & $50.88^{\mathrm{a}} \pm 1.68$ & $47.69^{\mathrm{b}} \pm 2.40$ & $<0.001$ \\
$\mathrm{a}^{*}$ & $4.45^{\mathrm{b}} \pm 0.50$ & $5.08^{\mathrm{a}} \pm 0.67$ & $<0.001$ \\
$\mathrm{~b}^{*}$ & $3.69^{\mathrm{b}} \pm 0.65$ & $3.90^{\mathrm{a}} \pm 0.71$ & $<0.002$ \\
PSE (\%) & 28.35 & 6.7 & \\
DFD (\%) & 1.2 & 10.3 & $<0.001$ \\
DOA (\%) & $0.23^{\mathrm{a}}$ & $0.001^{\mathrm{b}}$ & \\
\hline
\end{tabular}

${ }^{\mathrm{a}-\mathrm{b}}$ Mean \pm standard deviation in the same row with no common superscripts are significantly different by Student ttest $(\mathrm{P}<0.01)$.

According to the results reported herein, $\mathrm{L} *$ values in the winter were lower than those found in the summer season. Corroborating with these results, McCurdy et al. ${ }^{12}$ in Canada also showed lower $\mathrm{L}^{*}$ in winter and high values in summer. These authors reported a higher incidence of PSE meat in summer $(15 \%)$ and similar to the results obtained where the incidence of PSE was $21.7 \%$ higher (Table 4) compared to winter season. Stress before slaughter such as heat stress and weather climate accelerate antemortem muscle metabolism and influence on meat quality. The physiology impact about the stress in animals has been the subject of several studies ${ }^{2,} 6,8,21,23$. In the development of the PSE meat the glycogen reserves are rapidly consumed due to metabolism changes caused by stress before slaughter, this event leading to rapid postmortem glycolysis that lowers the $\mathrm{pH}$ while the carcass is still warm. Hence, the sharp drop in $\mathrm{pH}$ and the high temperature of the carcass cause the denaturation of myofibrillar and sarcoplasmic proteins $4,7,8,14$.

The high incidence of DFD meat $(10.3 \%)$ in the winter months is probably the result of the combined effects of low ambient temperature and transport temperature, as shown in Table 2. These conditions are common in the winter season in southern Brazil. Exposure to extreme environmental temperatures during transportation could affect the body temperature of birds, which physiologically is normally between 40.5 and $42.5^{\circ} \mathrm{C}{ }^{5}$. It is suggested that cold temperature exposure during transport causes glycogen depletion in the muscle of the birds due to increased energy consumption to maintain normal body temperature under these conditions. As a result, these birds have less muscle glycogen stores at the time of slaughter to convert to lactic acid and lower the $\mathrm{pH}$ of the meat ${ }^{5,7,8,21}$. 
The DOA values were different between treatments (Table 4), suggesting that those values were related to thermal stress during the summer months, as the PSE meat incidence indicated. The commercial company where this study was conducted has a relatively effective practice regarding animal welfare compared to Petracci et al. ${ }^{31}$ that reported an average of $0.48 \%$ DOA (turkey) in Italy. The season conditions influenced the pre-slaughter mortality rate in turkeys also seen in other reports. DOA prevalence was higher in turkeys in the summer $(0.52 \%)$ compared to autumn $(0.29 \%)$, winter $(0.29 \%)$, and spring $(0.32 \%)(29)$ in Italy. Vieira et al. ${ }^{32}$ reported that the mortality incidence in the summer was $0.42 \%$, followed by spring $(0.39 \%)$, winter $(0.28 \%)$, and autumn $(0.23 \%)$ in Brazil. The thermal sensation of the seasons calculated by heat (HI) and cold (WC) (Table 2) affects the turkey meat characteristics such as $\mathrm{pH}, \mathrm{L}^{*}, \mathrm{a}^{*}, \mathrm{~b}^{*}$ and occurrence of PSE and DFD meat, as well as animal welfare.

\section{CONCLUSION}

The incidence of DFD turkey meat is higher in winter and PSE turkey meat in summer, as well as DOA index in summer season in a southern region of Brazil. These results suggest, as the first priority to introduce management tools to maintain animal welfare and thus preventing stressful conditions for the birds consequently keeping the quality of the breast fillet meat.

\section{ACKNOWLEDGEMENTS}

This project was funded by CNPq Proc. 471609/2011-0. RHC was under CAPES and Fundação Araucária graduate scholarship. EII and $\mathrm{AO}$ are CNPq Research Fellows, and MS (in memoriam) was a Brazilian Senior Visiting Professor Scholar from CAPES/UTFPR.

\section{REFERENCES}

1. USDA, United States Department Of Agriculture. (2017). FAS databases.

2. Carvalho RH, Soares AL, Honorato DCB, Guarnieri PD, Pedrão MR, Paião FG, Oba A, Ida EI, Shomokomaki M. The incidence of pale, soft, and exudative (PSE) turkey meat at a Brazilian commercial plant and the functional properties in its meat product. LWT - Food Sci Technol. 2014; 59(2): 883-8. Available from: http://www.sciencedirect.com/science/article/pii/S0023643814004502

3. Solomon MB, Laack RJM, Eastridge JS. Biophysical basis of Pale, Soft, Exudative (PSE) pork and poultry muscle: A review. J Muscle Foods. 1998;9(1):111. Available from: http://doi.wiley.com/10.1111/j.1745-4573.1998.tb00639.x

4. Wilhelm AE, Maganhini MB, Hernández-Blazquez FJ, Ida EI, Shimokomaki M. Protease activity and the ultrastructure of broiler chicken PSE (pale, soft, exudative) meat. Food Chem. 2010; 119(3): 1201-4. Available from: http://dx.doi.org/10.1016/j.foodchem.2009.08.034

5. Dadgar S, Lee ES, Leer TL V, Burlinguette N, Classen HL, Crowe TG, Shand J. Effect of microclimate temperature during transportation of broiler chickens on quality of the pectoralis major muscle. Poult Sci. 2010; 89(5): 1033-41. Available from: https://academic.oup.com/ps/article-lookup/doi/10.3382/ps.2009-00248

6. Spurio RS, Soares AL, Carvalho RH, Silveira Junior V, Grespan M, Oba A, Shimokomaki M. Improving transport container design to reduce broiler chicken PSE (pale, soft, exudative) meat in Brazil. Anim Sci J. 2016; 87(2): 277-283. Available from: 10.1111/asj.12407

7. Alvarado CZ, Sams AR. Turkey carcass chilling and protein denaturation in the development of pale, soft, and exudative meat. Poult Sci. 2004; 83(6): 1039-46. 
8. Owens CM, Hirschler EM, McKee SR, Martinez-Dawson R, Sams AR. The characterization and incidence of pale, soft, exudative turkey meat in a commercial plant. Poult Sci. 2000; 79(4): 553-8. Available from: http://www.ncbi.nlm.nih.gov/pubmed/10780653

9. Barbut S, Sosnicki AA, Lonergan SM, Knapp T, Ciobanu DC, Gatcliffe LJ, Wilson EW. Progress in reducing the pale, soft and exudative (PSE) problem in pork and poultry meat. Meat Sci. 2008; 79(1): 46-63. Available from: https://www.sciencedirect.com/science/article/pii/S0309174007002732?via\%3Dihu b

10. Owens CM, Sams AR. The influence of transportation on turkey meat quality. Poult Sci. 2000; 79(8): 1204-7.

11. Ngoka DA, Froning GW, Lowry SR, Babji AA. Effects of sex, age, preslaughter factors, and holding conditions on the quality characteristics and chemical composition of turkey breast muscles. Poult Sci. 1982; 61(10): 1996-2003. Available from: https://academic.oup.com/ps/article-lookup/doi/10.3382/ps.0611996 12. McCurdy RD, Barbut S, Quinton M. Seasonal effect on pale soft exudative (PSE) occurrence in young turkey breast meat. Food Res Int. 1996; 29(3-4): 363-6. Available from: http://linkinghub.elsevier.com/retrieve/pii/0963996996000208

13. Carvalho RH, Soares AL, Grespan M, Spurio RS, Coró FAG, Oba A, Shimokomaki M. The effects of the dark house system on growth, performance and meat quality of broiler chicken. Anim Sci J. 2015; 86(2): 189-193. Available from: 10.1111/asj.12262

14. Carvalho RH, Honorato DCB, Guarnieri PD, Soares AL, Pedrao MR, Paiao FG, Ida EI, Shimokomaki M. Glycolysis rate delay in Turkey breast Pectoralis major $\mathrm{m}$. in a commercial air chilling processing line and meat qualities. Int J Poult Sci. 2015;14(9): 516-520. Available from: http://www.scialert.net/abstract/?doi=ijps.2015.516.520

15. NOAA - National Weather Service. The heat index equation. Accessed 20 Dec. 2017. http://www.hpc.ncep.noaa.gov/html/heatindex_equation.shtml.

16. Mitchell MA, Kettlewell PJ. Transport and handling. In: Weeks C, Butterworth A, editors. Measuring and auditing broiler welfare. Wallingford; 2004. p.145-160.

17. NOAA. In: National Weather Service. The Heat Index Equation. 2017. http://www.hpc.ncep.noaa.gov/html/windchiilindex_equation.shtml. Accessed 20 Dec 2017.

18. Hamm R. Biochemistry of meat hydration. Advances Food Res.1961; 10: 355463. Available from: https://doi.org/10.1016/S0065-2628(08)60141-X

19. Carvalho RH, Ida EI, Madruga MS, Martínez SL, Shimokomaki M, Estévez M. Underlying connections between the redox system imbalance, protein oxidation and impaired quality traits in pale, soft and exudative (PSE) poultry meat. Food Chem. 2017; 215:129-37. Available from: http://linkinghub.elsevier.com/retrieve/pii/S0308814616312158

20. Simões GS, Oba A, Matsuo T, Rossa A, Ida EI. Vehicle Thermal Microclimate Evaluation during Brazilian Summer Broiler Transport and the Occurrence of PSE ( Pale , Soft , Exudative ) Meat. Braz Arch Biol Technol. 2009; 52:195-204. Available from: http://www.scielo.br/scielo.php?script=sci_arttext\&pid=S151689132009000700025

21. Carvalho RH, Honorato DCB, Guarnieri PD, Soares AL, Pedrão MR, Oba A, Ida EI, Shimokomaki M. Assessment of turkey vehicle container microclimate on transit during summer season conditions. Int J Biometeorol. 2018; 1-10. Available from: http:https://doi.org/10.1007/s00484-018-1498-2

22. Langer ROS, Simões GS, Soares AL, Oba A, Rossa A, Shimokomaki M, Ida EI. Broiler transportation conditions in a Brazilian commercial line and the occurrence of breast PSE (Pale, Soft, Exudative) meat and DFD-like (Dark, Firm, Dry) Meat. Brazilian Arch Biol Technol. 2010; 53(5): 1161-7. Available from: http://dx.doi.org/10.1590/S1516-89132010000500021

23. Carvalho RH, Honorato DCB, Guarnieri PD, Soares AL, Pedrão MR, Oba A, Ida EI, Shimokomaki M. In-transit development of color abnormalities in turkey breast meat during winter season. J Anim Sci Technol. 2018; 59(1): 30. Available from: https://doi.org/10.1186/s40781-017-0157-1

24. Pereira DF, Nääs IA. Estimating the thermoneutral zone for broiler breeders 
using behavioral analysis. Comput Electron Agric. 2008; 62(1): 2-7. Available from: https://doi.org/10.1016/j.compag.2007.09.001

25. Chan JTY, Omana DA, Betti M. Effect of ultimate $\mathrm{pH}$ and freezing on the biochemical properties of proteins in turkey breast meat. Food Chem. 2011; 127(1): 109-17. Available from: http://dx.doi.org/10.1016/j.foodchem.2010.12.095

26. Kauffman RG, Sybesma W, Smulders FJM, Eikelenboom G, Engel B, van Laack RLJM, Sterrenburg P, Nordheim EV, Walstra P, van der Walb PJ. The effectiveness of examining early post-mortem musculature to predict ultimate pork quality. Meat Sci. 1993; 34(3): 283-300. Available from: https://doi.org/10.1016/0309-1740(93)90078-V

27. Barbut S. Colour measurements for evaluating the pale soft exudative (PSE) occurrence in turkey meat. Food Res Int. 1993; 26(1): 39-43. Available from: https://doi.org/10.1016/0963-9969(93)90103-P

28. Barbut S. Estimates and detection of the PSE problem in young turkey breast meat. Can J Anim Sci. 1996; 76(3): 455-7. Available from: http://pubs.aic.ca/doi/abs/10.4141/cjas96-066\#citart1

29. Barbut S. Estimating the magnitude of the PSE problem in poultry. J Muscle Foods. 1998; 9(1): 35-49. Available from: http://doi.wiley.com/10.1111/j.17454573.1998.tb00642.x

30. Abebe A, Daniels J, McKean J, Kapenga J, Statistics and Data Analysis, Department of Statistics, Western Michigan University, Michigan, 2001.

31. Petracci M, Bianchi M, Cavani C, Gaspari P, Lavazza A. Preslaughter mortality in broiler chickens, turkeys, and spent hens under commercial slaughtering. Poult Sci. 2006; 85(9): 1660-4. Available from: https://doi.org/10.1093/ps/85.9.1660

32. Vieira FMC, Silva IJO, Barbosa Filho JAD, Vieira AMC, Broom DM. Preslaughter mortality of broilers in relation to lairage and season in a subtropical climate. Poult Sci. 201; 90(10): 2127-33. Available from: https://doi.org/10.3382/ps.2010-01170 